\title{
Alimentary Risk of Mycotoxins for Humans and Animals
}

\author{
Jagoda Kępińska-Pacelik (D) and Wioletta Biel *(D) \\ Department of Monogastric Animal Sciences, Division of Animal Nutrition and Food, \\ West Pomeranian University of Technology in Szczecin, Klemensa Janickiego 29, 71-270 Szczecin, Poland; \\ jagoda.kepinska-pacelik@zut.edu.pl \\ * Correspondence: wioletta.biel@zut.edu.pl
}

check for

updates

Citation: Kepińska-Pacelik, J.; Biel, W. Alimentary Risk of Mycotoxins for Humans and Animals. Toxins 2021, 13, 822. https://doi.org/10.3390/ toxins13110822

Received: 21 October 2021

Accepted: 19 November 2021

Published: 21 November 2021

Publisher's Note: MDPI stays neutral with regard to jurisdictional claims in published maps and institutional affiliations.

\begin{abstract}
Mycotoxins can be found in many foods consumed by humans and animals. These substances are secondary metabolites of some fungi species and are resistant to technological processes (cooking, frying, baking, distillation, fermentation). They most often contaminate products of animal (beef, pork, poultry, lamb, fish, game meat, milk) and plant origin (cereals, processed cereals, vegetables, nuts). It is estimated that about $25 \%$ of the world's harvest may be contaminated with mycotoxins. These substances damage crops and may cause mycotoxicosis. Many mycotoxins can be present in food, together with mold fungi, increasing the exposure of humans and animals to them. In this review we characterized the health risks caused by mycotoxins found in food, pet food and feed. The most important groups of mycotoxins are presented in terms of their toxicity and occurrence.
\end{abstract}

Keywords: feed; food; pet food; microbiological hazards; safety; mycotoxins

Key Contribution: Description of health risks posed by mycotoxins in food, pet food, and feed. Characteristic of most important groups of mycotoxins in terms of their toxicity and occurrence.

\section{Introduction}

Currently, despite many available methods of monitoring and preventing food contamination, there are threats that we are not able to completely eliminate. One of the sources of such threats are secondary metabolites of mold fungi-mycotoxins. The name is derived from the Greek word mycos (fungi) and Latin toxicum (poison). Many mycotoxins have been characterized, but the most important in terms of food safety are: aflatoxins, deoxynivalenol, fumonisins, zearalenone, and ochratoxin A. These basic forms of mycotoxins can be converted into metabolites with altered chemical structures and different physicochemical, chemical, and biological properties. Modified forms may arise in raw materials intended for food production and during technological processes [1]. Modified mycotoxins can also be produced by fungi or as part of an infected plant's defense mechanism [2].

The interest in mycotoxins results mainly from their physicochemical properties, such as their high stability in changing environmental conditions and their high toxicity [3]. Even low levels of mycotoxins in food can lead to serious health consequences, especially because, as low-molecular and thermostable substances, they are resistant to most technological processes, e.g., cooking, frying, baking, distillation, and fermentation [4]. Every day, both humans and animals are exposed to low-doses of mycotoxins [5-7].

The occurrence of mycotoxins not only affects the health of consumers, but also exerts an impact on global trade. Long-term consumption of mycotoxin-containing pet-food and feed by animals may decrease the production of milk, meat, or wool, and alterations to the reproduction and growth of animals can be detected. The potential toxicity of mycotoxins on the biological performance of animals, such as pigs and chickens, has been reported in the literature. Additionally, weight loss, immunosuppression with increased prevalence of diseases, and decreased reproductive capacity are some of the main risks associated with the consumption of foods contaminated by secondary metabolites of fungi [8]. 
Therefore, the aim of this review is to highlight the health risks posed by mycotoxins in food, pet food, and feed. The most important groups of mycotoxins in terms of their toxicity and occurrence are presented.

\section{Mycotoxin Contamination}

It is estimated that $25 \%$ of world plant production and $20 \%$ in the European Union may be contaminated with mycotoxins [9]. They are most often produced by fungi of the genera Aspergillus, Penicillium, Fusarium, and Alternaria (Figure 1). Their synthesis depends largely on the properties of fungal strains (physiological, genetic, and biochemical), as well as external factors, such as humidity and temperature. This means that the level of mold contamination depends, inter alia, on local weather conditions, because high humidity, optimal temperatures, and specific environments affect their formation.

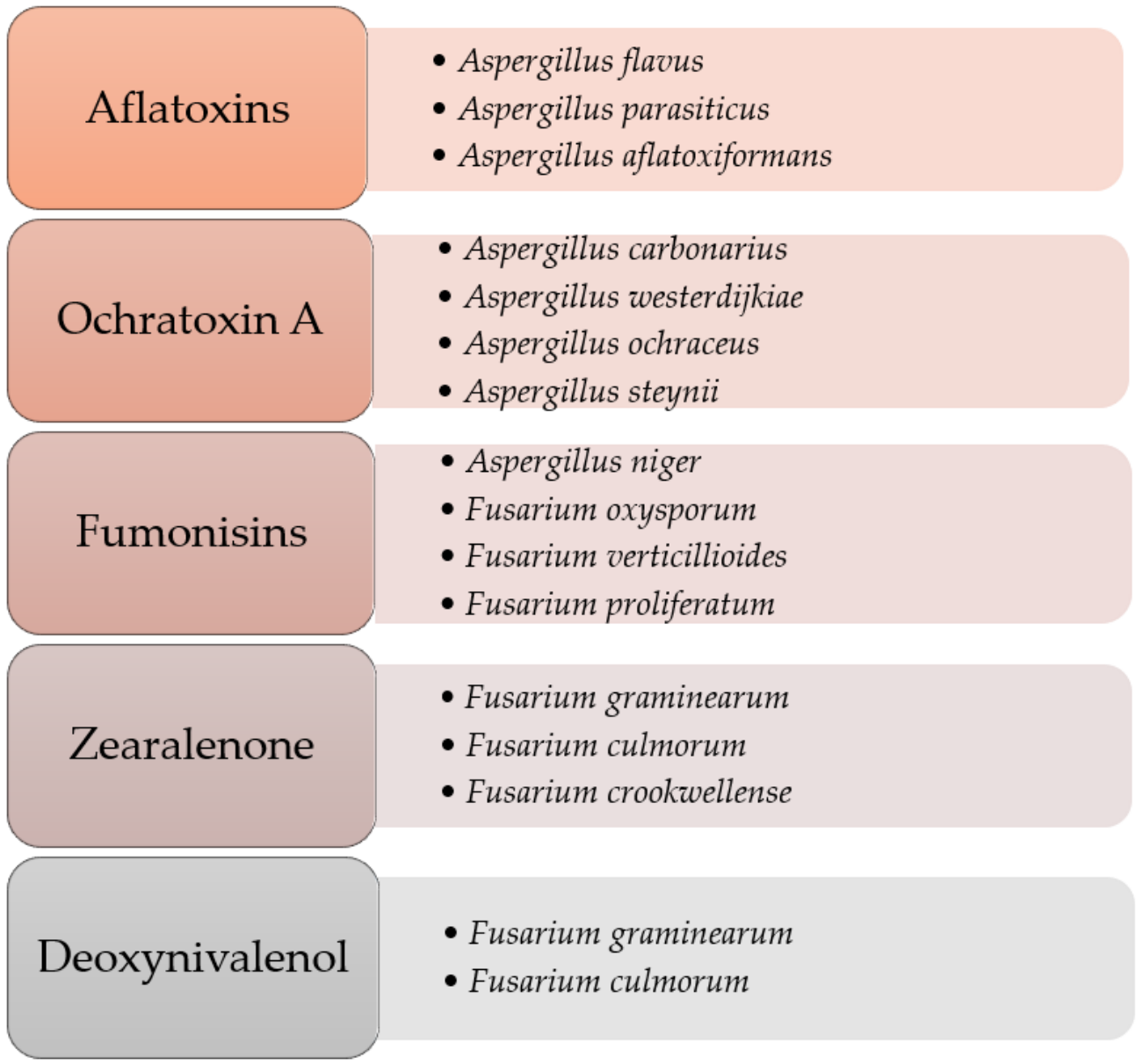

Figure 1. Selected species of mold fungi producing mycotoxins. Adapted from [10-12].

Most often, mycotoxins contaminate plant-based products, such as cereals, vegetables, dried fruits, nuts, coffee, cocoa, and tea. They can even be present in wine and beer [13]. However, plant products are not the only sources of mycotoxins. This can also apply to raw materials and products of animal origin (e.g., milk, meat) [14-16]. Mold toxins are characterized by a low molecular weight $(\mathrm{M}<1.5 \mathrm{kDa})$. They can be absorbed through the digestive and respiratory tracts, as well as through the skin and mucous membranes. Individual mycotoxins can be genotoxic, mutagenic, and teratogenic. Diseases caused by mycotoxins are called mycotoxicosis [17]. In the European Union, the issue of the maximum levels of certain contaminants in foodstuffs is regulated by the Commission Regulation (EC) No. 1881/2006 [18]. The acceptable levels of secondary metabolites of mold fungi in selected foodstuffs are presented in Table 1. 
Table 1. Maximum levels for certain mycotoxins in selected foods. Adapted from [18].

\begin{tabular}{|c|c|c|}
\hline Mycotoxins & Food Products/Raw Material & Maximum Level $[\mu \mathrm{g} / \mathrm{kg}]$ \\
\hline \multirow{3}{*}{$\begin{array}{l}\text { Sum of aflatoxin } \\
B_{1}, B_{2}, G_{1} \text { and } G_{2}\end{array}$} & $\begin{array}{l}\text { Groundnuts and nuts and processed products thereof, intended for direct } \\
\text { human consumption or use as an ingredient in foodstuffs }\end{array}$ & 4 \\
\hline & $\begin{array}{l}\text { Maize to be subjected to sorting or other physical treatment before human } \\
\text { consumption or use as an ingredient in foodstuffs }\end{array}$ & 10 \\
\hline & $\begin{array}{l}\text { Dried fruit and processed products thereof, intended for direct human } \\
\text { consumption or use as an ingredient in foodstuffs }\end{array}$ & 4 \\
\hline \multirow{3}{*}{ Ochratoxin A } & Unprocessed cereals & 5 \\
\hline & Roasted coffee beans and ground roasted coffee, excluding soluble coffee & 5 \\
\hline & $\begin{array}{l}\text { Processed cereal-based foods and baby } \\
\text { foods for infants and young children }\end{array}$ & 0.5 \\
\hline \multirow{4}{*}{ Deoxynivalenol } & Unprocessed cereals & $1250-1750$ \\
\hline & Pasta (dry) & 750 \\
\hline & $\begin{array}{l}\text { Bread (including small bakery wares), pastries, biscuits, } \\
\text { cereal snacks and breakfast cereals }\end{array}$ & 500 \\
\hline & $\begin{array}{l}\text { Processed cereal-based foods and baby foods for } \\
\text { infants and young children }\end{array}$ & 200 \\
\hline \multirow[t]{2}{*}{ Zearalenone } & $\begin{array}{c}\text { Bread (including small bakery wares), pastries, biscuits, cereal } \\
\text { snacks and breakfast cereals, excluding maize snacks } \\
\text { and maize based breakfast cereals }\end{array}$ & 50 \\
\hline & Processed maize-based foods for infants and young children & 20 \\
\hline \multirow{2}{*}{$\begin{array}{l}\text { Sum of fumonisins } \\
\qquad B_{1} \text { and } B_{2}\end{array}$} & Unprocessed maize & 2000 \\
\hline & $\begin{array}{l}\text { Processed maize-based foods and baby foods } \\
\text { for infants and young children }\end{array}$ & 200 \\
\hline
\end{tabular}

As mentioned earlier, mycotoxins contaminate many plant-based products. An example is green tea leaves, the infusion of which is one of the most consumed beverages in the world. Research [19] found that of the green tea samples available in Morocco, $56 \%$ was contaminated with at least one mycotoxin. The highest level was found for ZEN. Although many mycotoxins coexisted in the samples, probable daily intake estimates showed that the ingestion of mycotoxins through consumption of green tea does not pose a risk to the population.

\section{Harmful Effect of Mycotoxins for Humans and Animals}

\subsection{Classification}

The toxic effect of metabolites of mold fungi is diverse and depends on the chemical structure [20]. Depending on the damaged organ, mycotoxins can be divided into:

- Dermatotoxins-damaging mucous membranes and skin;

- Hepatotoxins-leading to liver damage;

- Cardiotoxins-causing cardiovascular diseases;

- Nephrotoxins-damaging the kidneys;

- Neurotoxins-affecting the central nervous system;

- Pulmotoxins-causing pulmonary edema.

In addition, there are also a different classification of mycotoxins:

- Immunotoxins-negatively affecting the immunological system;

- Micohormones-negatively influencing hormonal regulation;

- Carcinogenic compounds-leading to the formation of neoplasms. 


\subsection{Aflatoxins}

Different classes of aflatoxins (AF), such as $B_{1}, B_{2}, G_{1}$, and $G_{2}$ can be recognized. The capital letters refer to the color they take under UV light (blue-B, green-G). AF can be found mainly in peanuts, maize seeds, and oilseeds. $\mathrm{AFB}_{1}$ is the most prevalent and most toxic compound among AFs. In the liver, it is transformed into $\mathrm{AFM}_{1}$, which is then excreted into the milk of lactating mammals, including dairy animals. AFM $\mathrm{AM}_{1}$ has been shown to be cause of both acute and chronic toxicosis. The presence of $\mathrm{AFM}_{1}$ in milk and dairy products represents a worldwide concern since even small amounts of this metabolite may be of importance as long-term exposure is concerned [21].

AF can also be found in meat. The plague of 100,000 turkeys in 1960 on poultry farms in England resulted in a fundamental revision of the assessment of the effects of fungal metabolites on other organisms and increased interest in them, as it turned out that disease " $\mathrm{X}$ " was caused by AF. AFs are considered to be the best-studied mycotoxins [22]. The consequences of AF poisoning vary, mainly due to the amount of the dose and whether it is short-term or chronic contact. The effects of poisoning are serious and can be fatal. The most common symptoms are abdominal pain, vomiting, hemorrhage, liver damage, growth and development impairment, immunodeficiency, pulmonary and limb edema, weakening of blood vessels, and coma [22-26]. Among the mycotoxins known so far, AF has the strongest carcinogenic effect. Its chronic presence in food products supplied to the body contributes to the formation of liver cancer [20]. The International Agency for Research on Cancer (IARC) has classified $\mathrm{AFB}_{1}$ as "group I" due to its high toxicity, teratogenicity, hepatocarcinogenicity, and mutagenicity. $\mathrm{AFB}_{1}$ is converted into its fundamental hydroxylated metabolite called $\mathrm{AFM}_{1}$ in the liver of livestock by a superfamily of enzymes called cytochrome $\mathrm{P} 450$ and ingestion of feed contaminated with $\mathrm{AFB}_{1}$ can cause excretion of aflatoxin $\mathrm{M}_{1}$ in milk. Depending on toxicity and carcinogenicity, in 2012, IARC has also classified $\mathrm{AFM}_{1}$ as "group I" [27,28].

The great toxicity of $\mathrm{AFB}_{1}$ is based on its bioactivation process. $\mathrm{AFB}_{1}$ is biologically activated by a number of P450 cytochromes (CYPs), namely CYP1A and CYP3A, to an extremely reactive and electrophilic derivative, AFB1-8,9-epoxide (AFBO), which binds DNA and proteins. Such AFBO-DNA and AFBO-protein adducts inhibit RNA and protein synthesis, ultimately leading to severe toxicity and eventually cancer development. The animal intake of AFs always accompanies the production of reactive oxygen species (ROS) and the resulting oxidative damage may be a major trigger of detrimental outcomes [29].

The effects of $\mathrm{AFB}_{1}$ on animals vary according to the concentration and duration of contact with mycotoxin in food. High concentrations of this toxin are lethal, moderate concentrations lead to chronic poisoning. Since about one-fifteenth of the consumed $\mathrm{AFB}_{1}$ is excreted in milk as $\mathrm{AFM}_{1}$, and different heat treatments used in the preparation of different dairy products do not reduce the amount of $\mathrm{AFM}_{1}$, there is always the possibility of poisoning with this toxin by consuming contaminated milk [30].

\subsection{Ochratoxin A}

Exposure to ochratoxins comes from the consumption of foodstuffs of plant origin (grape juice, wine, coffee, spices, dried fruits, chestnuts, cereal-based products, e.g., wholegrain breads), and animal origin, e.g., pork blood-based products [31]. The most important mycotoxin from this group is ochratoxin A (OTA) [20]. OTA is very resistant to thermal treatment and stable in an acid environment.

OTAs are found in many foods such as maize seeds, wheat, barley, oats, rye, rice, flour, coffee, cocoa, legumes. They are found also in some fermented products, such as wine, beer, soy sauce. Dried fruits are also characterized by high OTA content. OTA can also contaminate animal products, such as milk and meat, especially pork, the consumption of which poses a risk of developing OTA nephropathy and urinary tract cancers. OTA tends to accumulate in animal tissues as it is fat soluble [32]. OTA is highly toxic, causes neurotoxic and teratogenic effects, impairs immunity, and primarily damages the kidneys. OTA interferes with the activity of phenylalanine hydroxylase in the kidneys and liver, 
resulting in the inhibition of normal protein synthesis. It also inhibits RNA and DNA synthesis [33]. The harmfulness of OTA is caused by irreversible damage to nephrons, which in turn may lead to death. In 1993, it was recognized by the International Agency for Research on Cancer (IARC) as possibly carcinogenic for humans [34,35].

Among farm animals, pigs are the most susceptible to the accumulation of OTA, whose tissue deposition occurs as follows: kidney $>$ liver $>$ muscle $>$ fat. Even if OTA effects are known, the molecular mechanisms underlying the damage are still not completely clarified. OTA exposure (in vitro or in vivo) has been related to overproduction of reactive oxygen species (ROS), as well as oxidative damage (lipids, proteins, and DNA). In addition, OTA may reduce the antioxidant defense of cells by reducing GSH and cytoprotective enzymes [36].

OTA causes a dangerous disease called Balkan endemic nephropathy $[37,38]$. Moreover, for several years now, attention has been paid to the OTA contamination of white and red wines in Italy and other Mediterranean regions. The main species responsible for the production of this mycotoxin is the fungus Aspergillus carbonarius (Bainier) Thom, which grows on the fruit of grapes during harvest $[39,40]$.

\subsection{Trichothecenes}

Trichothecenes are small, amphipathic molecules that can move passively across cell membranes. They are easily absorbed via the integumentary and gastrointestinal systems, allowing for a rapid effect on rapidly proliferating tissues [41]. Several dozen trichothecenes have been described; however, only DON, T-2, and HT-2 toxins have drawn attention for public health so far [42]. In terms of chemical structure, they are divided into four groups: A, B, C, and D. The type-A trichothecenes (T-2 and HT-2 toxins, diacetoxyscirpenol) have a functional group other than a ketone at carbon position 8 . They occur less frequently but are more toxic than type-B trichothecenes [42]. The most common and well-studied is deoxynivalenol (DON), which usually occurs together with its two derivatives (3-acetyl and acetyl-deoxynivalenol). It mostly occurs as a result of infection with fungi of the genus Fusarium in maize, wheat, and other cereals grown in temperate climates [43]. Contact with DON in humans causes: vomiting, diarrhea, abdominal pain, headache, dizziness and fever [44,45]. It has been shown that infants and children are most susceptible to DON infestation [46].

Exposure to DON, as well as other trichothecenes, can have endocrine disruptive effects, such as reduced weight gain, neuroendocrine changes, and they also exert immune modulation. Acute exposure can cause leukocytosis, hemorrhage, and, with extremely high exposure, even death. This is the reason why, a few years ago, researchers raised questions about the safety of DON in exposed high-risk groups, including children and vegetarians [47].

\subsection{Zearalenone}

The sources of zearalenone (ZEN) are fungi of the genus Fusarium, often found in maize, wheat, barley, and other cereals [48]. Contamination of ZEN often occurs simultaneously with DON contamination and less frequently with AFs [42]. ZEN is stable at normal cooking temperatures and partially eliminated at high temperatures [49]. Due to its structural similarity to naturally occurring estrogens, it can be described as an estrogenic mycotoxin [20]. It causes changes in the reproductive system [48].

Because of its estrogenic properties, ZEN has been classified as a non-steroid estrogen or mycoestrogen, but its metabolites can show a 10-fold higher estrogenic activity than ZEN itself. Its major metabolites are zearalanone (ZAN), $\alpha$-zearalenol ( $\alpha \mathrm{ZOL}), \beta$-zearalenol ( $\beta Z O L), \alpha$-zearalanol ( $\alpha Z A L)$, and $\beta$-zearalanol ( $\beta Z A L)$. Similar to trichothecenes, $Z E N$ is rapidly absorbed from the gastrointestinal tract and metabolized. In animals, there are two main routes of ZEN biotransformation: hydroxylation, leading to the formation of $\alpha \mathrm{ZOL}$ and $\beta Z O L$, and conjugation of ZEN with glucuronic acid. ZEN and its metabolites can 
cause changes in the metabolic profile of steroid-dependent cells, such as granulosa cells of ovarian follicles [50].

ZEN has a destructive effect on hormonal balance [51]. Depending on the dose, symptoms such as increased uterine weight and the number of antral follicles in an ovary have been observed in rats $[52,53]$. The estrogenic potency of both types of ZEA metabolites is different. $\alpha$-ZOL demonstrates a higher binding capacity to estrogen receptors in comparison to the parent ZEA. In turn, $\beta$-ZOL has the lowest binding affinity of the three compounds. The species-specific rate of ZEA conversion to $\alpha$-ZOL can be considered as a bio-activation reaction while ZEA transformation into $\beta-\mathrm{ZOL}$ as an inactivation reaction [54].

\subsection{Fumonisins}

Fumonisins (FB) are a family of more than 25 mycotoxins produced by fungi of the genus Fusarium, the most common of which are fumonisin $\mathrm{B}_{1}\left(\mathrm{FB}_{1}\right)$ and $\mathrm{B}_{2}\left(\mathrm{FB}_{2}\right)$ [55]. Maize seeds are the most susceptible to infection, although the presence of these mycotoxins can be also found in sorghum, wheat, barley, soybeans, asparagus, figs, and black tea. They are the most common mycotoxins in maize seeds [11]. FBs are hydrophilic mycotoxins. They are structurally different from most other mycotoxins that can be completely dissolved in organic solvents. Due to their hydrophilicity, FB does not get into milk, but small amounts accumulate in animal tissues, which are later used as raw materials for the food industry. FBs impair the functioning of the kidneys. They are also classified as neurotoxins because they damage the sphingosine biosynthetic pathway as a component of brain and nervous tissue [56]. $\mathrm{FB}_{1}$ can cause a variety of diseases in animals, for example equine leukoencephalomalacia, porcine pulmonary edema syndrome, hepatic tumor in rats, acute and fatal nephrotoxicity and hepatotoxicity in lambs. Varying degrees of toxic reactions (e.g., reduced weight gain, increased mortality, reduced size of the bursa of Fabricius, thymus, and spleen, myocardial degeneration, myocardial hemorrhage, alterations in the hemostatic mechanism and necrosis of hepatocytes) have been observed in chickens, ducks, and turkey chicks. Therefore, this mycotoxin not only pose a serious threat to human and animal health, but also affects food safety and limits animal production [57].

One of the paradoxes related to the toxicity of FB in animals concern the toxicokinetics of FB at the onset of mycotoxicosis. Most studies on animals concluded that FB toxicity is cumulative. In avian species, prolonged exposure of ducks and turkeys to low doses of FB resulted in a gradual increase in sphinganine (Sa) and sphingosine (So) bases over time in the liver; Sa and So being recognized markers of FB exposure and toxicity. However, toxicokinetic studies conducted both in avian species and in mammals revealed that FB is rapidly eliminated from the blood, and persistence of FB in animals was considered to be negligible. The apparent paradox between the cumulative toxicity of FB and their rapid plasma elimination may in fact be related to the lack of sensitivity of the analytical methods used [58].

\subsection{Modified and Masked Mycotoxins}

It has been noted for some time that the levels of mycotoxins found in food may be underestimated due to the presence of modified mycotoxins [59].

Modified mycotoxins are metabolites of mold fungi that normally are undetected when the parent mycotoxin is tested. These modified forms of mycotoxins can be produced by fungi or generated as part of an infected plant's defense mechanism. In some cases, they are formed during food processing. The different processing steps influence the levels of mycotoxins present in the final product [60]. Research indicates that some modified mycotoxins can be converted into parent mycotoxins as a consequence of digestive processes in humans and animals, which can lead to adverse health effects. The resulting compounds may be even more toxic as long as their bioavailability is greater than that of the parent mycotoxin. Although the toxicological data are scarce, the possibility of converting a modified mycotoxin to its free form can pose a potential health risk, not only to humans but also to animals [2]. Masked mycotoxins are derivatives of mycotoxins that 
are undetectable by conventional analytical techniques due to the fact that their structures changed in the plant [60]. Conventional methods, for example ELISA, respond to masked forms, while this is unlikely with HPLC-based methods. It has been suggested that the analysis of the mycotoxin content in samples containing these compounds leads to their underestimation. Masked mycotoxins may not be detected during analyses due to altered physicochemical properties of their molecules [61]. Recognition that masked mycotoxins are of toxicological importance in food products suggests that generic toxicity estimates should be developed to be used by regulators and food producers to protect the health of consumers.

Of the masked mycotoxins, deoxynivalenol-3-glucoside (DON-3-G) and zearalenone sulfate (ZEA-S) are the most common in food and feed. Their toxicological properties are currently being investigated and the main concern is related to the conversion of DON-3-G to DON and ZEA-S to UAE by the microbiota of the gastrointestinal tract [62]. It is a group of chemically differentiated mycotoxins for which, to date, no legal regulations regarding safe levels in food and feed exist, and risk assessment studies are still ongoing. Moreover, there is no clear indication of the toxicity of other fungal secondary metabolites, which are often found in cereals, such as aurofusarin (AUR) and coulmorin (CULM), and are still under extensive research. In addition, there is a lack of information on the fate of masked, modified, and emerging mycotoxins and other secondary fungal metabolites in corn products and by-products [63], which are a significant raw material in the food industry, but are also raw material for the production of food and animal feed.

It is worth emphasizing that many structurally related substances, referred as modified mycotoxins, are generated by plant or fungal metabolism, as well as by food processing and coexist with their native forms [64]. As a result of their complex and variable chemical structure and ubiquitous presence, humans and animals may potentially be exposed to one or more mycotoxins or their forms modified by eating a contaminated diet. Studies [65] have shown that the presence of modified forms of mycotoxins is more often reported in food compared to feed. In addition to the presence of ZEN and its modified forms of phase I and phase II biotransformation, only a limited amount of quantitative data is available for the other modified forms, e.g., acetyl DON derivatives, hydrolyzed FBs, phase I metabolites T2 and NIV3G. Moreover, data are still scare and unevenly reported, despite increased awareness of the contribution of modified forms to the toxicity of mycotoxins. Overall, there have been recent promising advances in the field of analytical methods, which is a positive indicator of upcoming improvements in the simultaneous determination of multiple mycotoxins, both native and modified forms. However, analytical methods are still a limiting factor in complete data collection, both in terms of cost and lack of appropriate protocols [65].

\section{Methods of Preventing Synthesis of Mycotoxins}

The main strategy against the presence of mycotoxins in food, pet-food, and feed is to prevent the growth of the molds that produce them. Many methods are used today, from improved agricultural practices to traditional cultivation of resistant plant varieties and the use of genetic engineering. An important aspect turns out to be the monitoring of weather conditions conducive to the development of molds,; thanks to the maps of metrological data it is possible to predict the occurrence of the mycotoxin. Agrotechnical measures aimed at preventing the formation of mycotoxins include, inter alia, appropriate fertilization, and crop rotation. The soil is the main reservoir of spores for the fungi of the genus Fusarium. Their concentration in the substrate is increased by the continuous cultivation of one plant species, which results in an increased risk of plant infection [66]. A preventive measure is also the selection of plant varieties that are resistant to infection by mold fungi. Another example is the use of measures to protect plants against the growth of weeds and insects, because weeds provide a shelter for developing mold fungi, while insects are responsible for transferring fungal spores and damaging plant tissues and seeds, which facilitates the penetration of pathogens [67]. Timely harvesting with minimal moisture, and the proper 
storage of raw materials, are also important. In the European Union, agricultural practices are carried out in accordance with "Good Agricultural Practice" (GAP). Attention is paid to carrying out agrotechnical operations in such a way as not to cause the growth of the inoculum of fungi in agricultural crops and in production fields. In the case of already harvested raw materials, sorting them is the safest method of fighting mycotoxins. Optical sorting consists in separating damaged, discolored and generally abnormal-looking seeds, nuts, rice, legumes, fruits, etc., from those that show the correct characteristics for their species. The concentration of mycotoxins is significantly reduced as a result of washing and hulling the grains. Another method of eliminating mold fungi is the use of gamma and UV radiation, but this method does not reduce the level of mycotoxins that have already been produced, but only limits the development of fungi [68]. Chemical methods, in turn, rely on the use of chemical compounds to absorb, displace, or inactivate mycotoxins. Among others, ammonia, hydrogen peroxide, and sulfur (IV) oxide are used, although they are not of practical use because they change the nutritional value of the products and involve the risk of creating hazardous residues. Commercial additives (containing, for example, clays, zeolites, activated carbon) that can absorb toxins in the digestive tract are available, so that they are not absorbed into the bloodstream. In the fight against mycotoxins, biological methods are also used, consisting in the use of microorganisms characterized by the ability to remove various toxins from the environment. They work by metabolizing mycotoxins without the risk of producing side metabolites that are harmful to humans and animals. This method, however, is controversial among consumers, mainly due to the lack of legal regulations regarding this issue, however, studies clearly indicate its effectiveness [68].

High hopes are placed on the use of Lactobacillus and Bifidobacterium bacteria on a larger scale, which in addition to metabolizing mycotoxins have health-promoting properties, thanks to which they increase the nutritional value of products. $L$. rhamnosus strains were found to be the most effective in binding AF. Strains of L. acidophilus and B. bifidum, B. longum and others, reduce the amount of $\mathrm{AFB}_{1}$ [69]. It has been shown that not only $\mathrm{AF}$ is effectively cleared by lactic acid bacteria. The research also confirms the ability of bacteria belonging to the species L. salivarius, L. delbrueckii subsp. bulgaricus and $B$. bifidum to reduce the amount of OTA [70]. Saccharomyces cerevisiae yeast is characterized by similar properties, mainly OTA. These microorganisms are used on a large scale in many biotechnological processes, e.g., in baking, brewing, winemaking, and distilling. Due to the frequent mycotoxin contamination of the raw materials used in these processes (flour, malt, grape must), the possibility of fermentation using strains is considered, which, apart from the appropriate technological features, show the ability to reduce the toxin content, thus increasing the safety of the obtained product. Some yeasts also have probiotic features, which additionally resulting in an increased interest in the possibilities of their use [69].

The studies [71] showed that adding the Biobardin feed additive to the feed of broiler chickens in the amount of 5\% may reduce the negative effects of the consumption of mycotoxins produced by the mold fungi Fusarium graminearum, F. sporotrichiella, F. poae, and F. moniliformeobecne. This addition in compound feed has an impact on the productivity of poultry and the prevention of mycotoxicity. Poultry suffering from chronic forms of mycotoxins were able to assimilate nutrients more efficiently than poultry that consumed similar feed free from the analyzed additives. It has been found that the consequences of chronic mycotoxicosis in poultry can be reduced by $25-50 \%$.

Complete elimination of mycotoxins from feed is impossible, so effective mitigation programs are in place that can reduce the bioavailability of mycotoxins in the animal's gastrointestinal tract. The use of natural products seems to be interesting. A study [72] evaluated the effect of various concentrations of the mixture of zeolite and bee brood in the diets of broilers under the influence of T-2 mycotoxin. It was shown that introducing a mixture of zeolite and bee brood into the diet of broiler chickens had a significant positive effect on the increase in live weight and blood parameters, reducing the negative effect of mycotoxins. Thus, the addition of zeolite and bee brood product to the diet has some protective effect when exposed to the T-2 mycotoxin produced by Fusarium fungi. 
According to the World Health Organization (WHO), natural antioxidants can be a good choice for the prevention and treatment of various types of toxicity compared to other therapeutic agents in terms of low price, safety, and efficacy [73]. Dietary antioxidants are a potential source of neutralizing oxidative stress and maintaining redox homeostasis. Natural antioxidants can be vitamins (E and C), metalloproteins (ferritin, lactoferrin and albumin), other biologically active substances (flavonoids, carotenoids and anthocyanins), or minerals. One of the key approaches to protecting the body from oxidative damage is to incorporate natural antioxidants into the daily diet [73]. Therefore, dietary antioxidants advocate an innovative approach to protecting the body from a variety of toxins by strengthening the body's internal antioxidant system against the negative effects of mycotoxins [74].

\section{Food}

The awareness of people around the world regarding safe and healthy food is growing, which is contributing to the creation of programs to detect and alert about the detection of hazardous substances. In the European Union, the food safety strategy includes the Rapid Alert System of Food and Feed (RASFF). The information obtained from the RASFF system enables risk prevention and early remedial action. The functioning of the system is based on the collection and quick dissemination of information about food products and feeds. Mycotoxin contamination of foodstuffs is the cause of a significant proportion of the notifications (around 20\% in the European RASFF network) [75].

Due to their high consumption, cereals pose a particular threat to humans as a potential source of mycotoxins. Consumption of pseudocereals (quinoa and kañiwa) is currently increasing, although little is known about the susceptibility of these crops to mycotoxin contamination. The study by Ramos-Diaz et al. [76] determined the levels of mycotoxins and metabolites of mold fungi in Andean grains (quinoa and kañiwa) compared to cereal grains (barley, oats, and wheat), grown both in South America (Bolivia and Peru) and Northern Europe (Denmark, Finland, and Latvia). A total of 101 analytes at different levels were detected, mainly produced by fungi of the genera Penicillium spp., Fusarium spp. and Aspergillus spp. Their presence depended on the type of crop, geographic location, and agricultural practices used. In general, pseudocereals from South America were less contaminated with mycotoxins than those from Northern Europe, while the opposite was true for cereals. The mycotoxin contamination profiles showed significant differences between pseudocereals and cereals, even when harvested from the same regions.

Meat and meat products can also be contaminated with mycotoxins, especially animal organs, such as the kidneys and liver, which are the main organs implied in the detoxification of xenobiotics. Alaboudi et al. [77], analyzing frozen and fresh meat and offal (liver, kidneys), showed the presence of mycotoxins ( $\mathrm{AFB}_{1}, \mathrm{OTA}, \mathrm{ZEN}, \mathrm{FB}_{1}$, and $\mathrm{DON}$ ) in all samples. It should be emphasized that $Z E N$ and $\mathrm{AFB}_{1}$ exceeded the MRLs of $14 \%$ and $2 \%$, respectively, in the samples of frozen chicken muscles. The liver contained ZEN, and the kidneys contained ZEN, $\mathrm{FB}_{1}$, and DON. ZEN levels were higher in the liver (30.0\%) than in the kidney samples $(8.0 \%)$. Such analyses and data may be useful for state food control authorities to implement monitoring and control of mycotoxin residues in all poultry meat products. However, it is not a rule that all offal can be contaminated with mycotoxins, because, as shown by van Deventer et al. [78], a lack of mycotoxins was observed in marker tissues (liver and kidney) and in muscle tissue obtained from registered slaughterhouses in South Africa.

Due to the sensitivity of infants, safe food is extremely important, especially in their case. Mammalian milk may contain contaminants from maternal exposure. Memis et al. [79] showed the presence of $\mathrm{AFM}_{1}, \mathrm{OTA}, \mathrm{ZEN}$, and DON in human milk. It was also shown that higher levels of OTA were associated with exposure to smoking (environmental, maternal smoking). The conclusion is that mycotoxins can pass into breast milk and maternal exposure to smoking may have an impact on this situation. Exposure to mycotoxins mentioned above can also lead to lactation problems. 
The study of milk substitutes [80] found the presence of 17 mycotoxins, including $\mathrm{AFB}_{1}, \mathrm{ZEN}, \mathrm{DON}$, and $\mathrm{FB}_{1}$. Infant formulas were less contaminated than grain products. It was found that the limit for baby food for $\mathrm{AFB}_{1}$ was exceeded in flour. Interestingly, two toxins not previously described in the literature, namely aflatoxicol and sterigmatocystin, were identified in $3 \%$ and $17 \%$ of baby food, respectively.

\section{Pet Food and Feed}

Apart from humans, animals can also be exposed to microbiological hazards. This is especially possible for companion animals, especially dogs and cats. Even dried dog snacks can be a source of such contaminants. Pet food may also be a hazard, and not only because of bacterial contamination [81]. Currently, research is being conducted to detect the contamination of mycotoxins in pet food. Pigłowski's analyses showed [75] that these substances were the most frequently reported hazard category in the RASFF system from 1981 to 2017. Importantly, the majority of reports concerned $\mathrm{AFB}_{1}$ [75]. In the case of animal food, the mycotoxins of most concern are AFs, OTA, ZEN, and FB [82]. However, a large group of EU recommendations for safe levels in animal products only apply to three mycotoxins (Table 2) [83].

Table 2. Guideline limit values for deoxynivalenol, zearalenone, and ochratoxin A in pet products. Adapted from [83].

\begin{tabular}{|c|c|c|}
\hline Mycotoxin & Pet Food Product & $\begin{array}{c}\text { Guide Value in } \mathrm{mg} / \mathrm{kg} \text { for a Pet Product with a } \\
\text { Moisture Content of } 12 \%\end{array}$ \\
\hline \multirow{3}{*}{ Deoxynivalenol } & $\begin{array}{l}\text { cereals and cereal products with the exception of } \\
\text { maize by-products }\end{array}$ & 8 \\
\hline & maize-by products & 12 \\
\hline & compound feed & 5 \\
\hline \multirow{4}{*}{ Zearalenone } & $\begin{array}{l}\text { cereals and cereal products with the exception of } \\
\text { maize by-products }\end{array}$ & 2 \\
\hline & maize-by products & 3 \\
\hline & $\begin{array}{l}\text { compound feed for adult dogs and cats other } \\
\text { than those intended for reproduction }\end{array}$ & 0.2 \\
\hline & $\begin{array}{c}\text { compound feed for puppies, kittens, dogs and } \\
\text { cats intended for reproduction }\end{array}$ & 0.1 \\
\hline \multirow{2}{*}{ Ochratoxin A } & cereals and cereal products & 0.25 \\
\hline & compound feed for dogs and cats & 0.01 \\
\hline
\end{tabular}

It has been shown that, in the case of cereals, most of the impurities are close to the grain surface. This means that removing only part of the outer layers of the grains can reduce mycotoxin contamination [84]. Research [85] showed that metabolites of lactic acid bacteria $(\mathrm{LAB})$ can be a valuable alternative in reducing fungal infections before and after harvest. It has been shown that mycotoxins present in food can lead to a reduction in food consumption and have a negative impact on animal health [86-88]. The presence of these substances may also inhibit overall weight gain, for example, in domestic animals [89].

In addition, the presence of mycotoxins in edible animal products, such as milk, meat, and eggs, is possible, which may have long-term negative health effects on humans $[90,91]$. Contamination with fungi and mycotoxins affects both the organoleptic properties and the nutritional value of the pet food and carries the risk of poisoning. Moreover, studies have shown that a high percentage of pet food samples are contaminated with more than one mycotoxin [92].

The individual sensitivity of animals, the amount of toxins present and the time of exposure are the main factors determining the effects of consuming food contaminated with mycotoxins $[92,93]$. $\mathrm{AFB}_{1}$ has been shown to have a strong hepatotoxic effect, but it can be minimized, for example, by supplementing the food with curcumin [94]. Control 
of the production of mycotoxins and the growth of molds responsible for their formation should be a priority issue for food producers, both for humans and animals [95]. A study by Singh and Chuturgoon [96], the purpose of which was to compare the microbiological quality of supermarket pet foods with premium foods, showed that regardless of the manufacturer, all food samples were contaminated with fungi (mainly Aspergillus flavus, Aspergillus fumigatus and Aspergillus parasiticus), as well as their secondary metabolites (most often AFs and FBs). The results of these studies indicate that more-expensive dog food does not provide the highest quality, and does not guarantee microbiological purity. It has been shown that in the case of dry animal food, the extrusion process can reduce the pathogenicity of microorganisms without affecting the digestibility of the food [97]. In subsequent studies focusing on the microbiological assessment of foods, a disturbing presence of FBs was found [98].

Mycotoxins are substances that are difficult to monitor continuously and a universal risk assessment tool would help to assess if there is a particular risk due to the inclusion of certain feed ingredients. To this end, a study [99] estimated the toxin content of 97 commercial fish feeds, with the most significant toxins in fish feed being DON, ZEN, FB and enniatin. They pose a risk to the welfare of fish, which can be calculated using Bayesian models to determine the $5 \%$ critical concentrations (CC5) for various toxins. Bayesian network (BN) modeling is one of the widespread machine learning modeling techniques, and can deal very well with both unbalanced data and missing data. BN models are developed on the basis of observational data. Such models make predictions by computing conditional probabilities among the available variables in the dataset [100].

In addition to fish meal, wheat, soy products, and corn are regularly used as fish feed ingredients. The calculated scenarios show that fish are at high risk of toxin contamination if low-quality feed ingredients are selected for feed production. It is therefore necessary to set specific maximum levels for several mycotoxins in fish feed [99].

Twarużek et al. [101] assessed the level of mycotoxin contamination of raw materials and products for animals in Poland in 2015-2020. Producers, farmers and veterinarians provided a total of 3980 samples (642 maize samples, 2027 feed samples, 990 fine grain samples, 142 maize silage samples and 179 TMR samples). The samples were analyzed for the presence of several mycotoxins, including AFs, FB, OTA, DON, ZEN, T-2 toxin, and $\mathrm{H}-2$ toxin. Studies have shown that DON and ZEN were the most common contaminants in maize samples (97.3\% and $98.4 \%$, respectively) and feed $(99.7 \%$ and $100 \%$ samples, respectively). They were also present in all maize and TMR silage samples. The highest concentrations of DON and ZEN were $16,889 \mu \mathrm{g} / \mathrm{kg}$ in the wheat sample and $1420 \mu \mathrm{g} / \mathrm{kg}$ in the maize sample. Additionally, in 51 trials, the level of mycotoxins (mainly DON and ZEN) exceeded those recommended by the European Union. The present study showed that both feed and raw materials are contaminated with mycotoxins, often by more than one [101].

Contamination of feeds with several types of FBs at the same time is quite common. It should be borne in mind, that mycotoxins show a synergistic effect. Especially the coexistence of FB with other toxins produced by Fusarium sp. Increases the risk. The research by Witaszak et al. [89] confirmed the presence of five mycotoxins in the amounts allowed by EU regulations. Despite this, caution should be paid because low levels of mycotoxins do not eliminate the risk in dog food, and long-term daily consumption of even small amounts of mycotoxins can lead to slow damage to the animal's body and the development of many diseases, including cancer. Mycotoxins were also found in food in the studies of Shao et al. [102]. Only one out of 32 samples was free of mycotoxin contamination. Moreover, all other samples were contaminated with at least three different types of mold secondary metabolites. Research by Tegzes et al. [103] aimed to compare grain and grain-free dog food in terms of mycotoxin content. The results of these analyzes confirmed the presence of mycotoxins in dry grain foods for dogs, while they were not found in grain-free foods. These analyses suggest that the risk of exposure to mycotoxins 
is higher with grain-based dry dog food. To minimize risk, dog food manufacturers should select grain types that are less susceptible to mycotoxins [104].

The main ingredient of veterinary therapeutic diets (VTD) is grain. These foods are intended for dogs with various diseases that require safe and nutritious nutrition. However, it is disturbing that cereal grains can quite often be contaminated with Fusarium fungi, which are responsible for the production of mycotoxins. In the studies by Witaszak et al. [105], samples of VTD were analyzed for the presence of molds and their secondary metabolites. Among the analyzed samples, only $9.5 \%$ were free from mycotoxins produced by Fusarium, however, none of the tested samples exceeded the permissible limits of mycotoxins content in pet food, as defined by EU regulations. It should be kept in mind, that systematic testing of both domestic and VTD for the content of harmful microorganisms and their metabolites is necessary, because especially VTD should be characterized by the highest level of safety for animals [81].

The research of Macias-Montes et al. [106] shows that the presence of mycotoxins is fairly common in dry dog food, however, the concentrations of most of them were among the lowest recorded so far. These studies showed that the food quality had no influence on the mycotoxin content. The problem may be chronic exposure to mycotoxins and their modified forms. The results of the research by Okuma et al. [107] revealed a low prevalence of AF and OTA in commercial pet foods. Although DON has been detected in many trials, its levels were well below those likely to cause acute toxic effects. On the other hand, studies by Gazzotti et al. [108] showed that all samples of extruded complete dog food complied with current European legislation on mycotoxin limits. However, these results reiterated the need for further research into the potential risk of chronic low-dose exposure to various types of mycotoxins to which pet species are currently exposed [81].

An important risk is seizure-forming mycotoxins. Penitrem A (PA) and roquefortine (RQ) are synthesized by some molds (Penicillium spp., P. crustosum and P. roqueforti). Their source is moldy food, mainly cereals and their products, e.g., bread, and various types of nuts (walnuts, almonds, peanuts), possibly also moldy dairy products. The cause of dog poisoning with roquefortine may also be ripening cheese with blue mold. This toxin is rapidly absorbed from the gastrointestinal tract. Its neurotoxic effect appears shortly after exposure $[109,110]$. Therefore, in connection with the above information, it is worth paying attention to the content of home garbage cans and garden composters. Perishable food that produces fungal toxins can pose a serious risk to companion animals.

In recent years, there has been a growing tendency to eat organic food instead of conventional food. This trend is mainly due to concerns about the potential negative health effects of consuming products containing pesticide residues, fertilizers, hormones and antibiotics, which are widely used in regular food production. While the legal acts governing the cultivation of organic raw materials prohibit the use of these products, environmental pollution can occur in both conventional and organic foodstuffs [111]. In the case of animal nutrition, grain-free food may turn out to be a safer solution in terms of mycotoxin content [103], although among pet food, especially the "premium" ones, raw materials from organic farming are more and more often used, and food from agriculture organic is considered safer in terms of pesticide content, but avoiding insecticides and fungicides in organic farming can lead to the growth of fungi and the formation of mycotoxins. This increases the likelihood of their occurrence in organic products, while increasing the consumer's exposure to these risks. Therefore, the safety function that has been assigned to organic food worldwide may be questionable depending on the potential environmental contamination of that food [112].

\section{Conclusions}

Both humans and animals are daily at risk of mycotoxins [5-7]. Due to the large amount of grain products consumed, it becomes extremely important to check them regularly for safety and to detect harmful substances. One of the most important indicators of the quality of food and pet food and feed is the content of mycotoxins in them. They are 
a threat that we are not able to completely eliminate from the surrounding environment. Their occurrence is favored by factors commonly present in our environment, including humidity. Modified mycotoxins may be a particularly significant risk. However, no legal regulations regarding safe levels in food and feed exist, and risk assessment studies are still ongoing. Mycotoxins show resistance to technological processes and have the ability to accumulate in tissues. They lead to economic losses and, in addition, they cause a wide variety of diseases for people and animals. Sometimes they can be the cause of death. As far as mycotoxins are concerned, milk, eggs, and meat do not constitute the main threat to human and animal health and life from the literature data. In most cases, their main source for humans and animals are eating contaminated grains and legumes and their products, and to a lesser extent food of animal origin. Research has shown that food products (such as cereal products, dried fruits, herbs and spices, wine) available on the market meet the applicable requirements for mycotoxin contamination and do not pose a threat to the health of consumers. However, the problem is mainly noticed in tropical and developing countries. The main strategy against the presence of mycotoxins in food, pet-food and feed is to prevent the growth of the molds that produce them. Many methods are used today, from improved agricultural practices to traditional cultivation of resistant plant varieties and the use of genetic engineering. Innovative methods include the use of zeolite, antioxidants and bacteria. Despite the fact that research on the content of mycotoxins in products is capital-intensive, it seems necessary to conduct monitoring in this area. In order to minimize the risk to the health of pets, the priority should be prevention, i.e., systematic testing of the raw materials and foods, in terms of the content of harmful microorganisms and their metabolites.

Author Contributions: Conceptualization, J.K.-P. and W.B.; methodology, J.K.-P. and W.B.; software, J.K.-P. and W.B.; validation, J.K.-P. and W.B.; formal analysis, J.K.-P. and W.B.; investigation, J.K.P. and W.B.; resources, J.K.-P. and W.B.; data curation, J.K.-P. and W.B.; writing-original draft preparation, J.K-P. and W.B.; writing—review and editing, J.K.-P. and W.B.; visualization, J.K.-P. and W.B.; supervision, J.K.-P. and W.B.; project administration, J.K.-P. and W.B.; funding acquisition, J.K.-P. and W.B. All authors have read and agreed to the published version of the manuscript.

Funding: The APC was funded by Grant of Rector of the West Pomeranian University of Technology in Szczecin for PhD students of the Doctoral School, grant number: ZUT/13/2021.

Institutional Review Board Statement: Not applicable.

Informed Consent Statement: Not applicable.

Conflicts of Interest: The authors declare no conflict of interest.

\section{References}

1. Humpf, H.U.; Rychlik, M.; Cramer, B. Modified mycotoxins: A new challenge? Food Chem. 2019, 1, 393-400. [CrossRef]

2. Freire, L.; Sant'Ana, A. Modified mycotoxins: An updated review on their formation, detection, occurrence, and toxic effects. Food Chem. Toxicol. 2018, 111, 189-205. [CrossRef]

3. Daou, R.; Joubrane, K.; Maroun, R.G.; Khabbaz, L.R.; Ismail, A.; El Khoury, A. Mycotoxins: Factors influencing production and control strategies. AIMS Agric. Food 2021, 6, 416-447. [CrossRef]

4. Karlovsky, P.; Suman, M.; Berthiller, F.; De Meester, J.; Eisenbrand, G.; Perrin, I.; Oswald, I.P.; Speijers, G.; Chiodini, A.; Recker, T.; et al. Impact of food processing and detoxification treatments on mycotoxin contamination. Mycotoxin Res. 2016, 32, 179-205. [CrossRef] [PubMed]

5. Brewer, J.H.; Thrasher, J.D.; Straus, D.C.; Madison, R.A.; Hooper, D. Detection of mycotoxins in patients with chronic fatigue syndrome. Toxins 2013, 5, 605-617. [CrossRef] [PubMed]

6. Claeys, L.; Romano, C.; De Ruyck, K.; Wilson, H.; Fervers, B.; Korenjak, M.; Zavadil, J.; Gunter, M.J.; De Saeger, S.; De Boevre, M.; et al. Mycotoxin exposure and human cancer risk: A systematic review of epidemiological studies. Compr. Rev. Food Sci. Food Saf. 2020, 19, 1449-1464. [CrossRef] [PubMed]

7. Chen, S.S.; Li, Y.H.; Lin, M.F. Chronic exposure to the Fusarium mycotoxin Deoxynivalenol: Impact on performance, immune organ, and intestinal integrity of slow-growing chickens. Toxins 2017, 9, 334. [CrossRef]

8. Peivasteh-Roudsari, L.; Pirhadi, M.; Shahbazi, R.; Eghbaljoo-Gharehgheshlaghi, H.; Sepahi, M.; Mirza Alizadeh, A.; Jazaeri, S. Mycotoxins: Impact on health and strategies for prevention and detoxification in the food chain. Food Rev. Int. 2021, 1, 1-32. [CrossRef] 
9. Eskola, M.; Kos, G.; Elliott, C.T.; Hajšlová, J.; Mayar, S.; Krska, R. Worldwide contamination of food-crops with mycotoxins: Validity of the widely cited 'FAO estimate' of 25\%. Crit. Rev. Food Sci. Nutr. 2020, 60, 2773-2789. [CrossRef] [PubMed]

10. Adekoya, I.; Njobeh, P.; Obadina, A.; Landschoot, S.; Audenaert, K.; Okoth, S.; De Boevre, M.; De Saeger, S. Investigation of the metabolic profile and toxigenic variability of fungal species occurring in fermented foods and beverage from Nigeria and South Africa using UPLC-MS/MS. Toxins 2019, 11, 85. [CrossRef] [PubMed]

11. Garcia-Diaz, M.; Gil-Serna, J.; Vázquez, C.; Botia, M.N.; Patiño, B. Comprehensive study on the occurrence of mycotoxins and their producing fungi during the maize production cycle in Spain. Microorganisms 2020, 8, 141. [CrossRef] [PubMed]

12. Tian, Y.; Tan, Y.; Yan, Z.; Liao, Y.; Chen, J.; De Boevre, M.; De Saeger, S.; Wu, A. Antagonistic and detoxification potentials of trichoderma isolates for control of zearalenone (ZEN) producing Fusarium graminearum. Front. Microbiol. 2018, 8, 2710. [CrossRef] [PubMed]

13. Pascari, X.; Ramos, A.J.; Marín, S.; Sanchís, V. Mycotoxins and beer. Impact of beer production process on mycotoxin contamination. Int. Food Res. J. 2018, 103, 121-129. [CrossRef]

14. Mohammedi-Ameur, S.; Dahmane, M.; Brera, C.; Kardjadj, M.; Ben-Mahdi, M.H. Occurrence and seasonal variation of aflatoxin M1 in raw cow milk collected from different regions of Algeria. Vet. World 2020, 13, 433-439. [CrossRef]

15. Nazhand, A.; Durazzo, A.; Lucarini, M.; Souto, E.B.; Santini, A. Characteristics, occurrence, detection and detoxification of aflatoxins in foods and feeds. Foods 2020, 9, 644. [CrossRef]

16. Muaz, K.; Riaz, M.; de Oliveira, C.A.F.; Akhtar, S.; Ali, S.W.; Nadeem, H.; Park, S.; Balasubramanian, B. Aflatoxin M1 in milk and dairy products: Global occurrence and potential decontamination strategies. Toxin Rev. 2021, 35, 1-18. [CrossRef]

17. Janik, E.; Niemcewicz, M.; Ceremuga, M.; Stela, M.; Saluk-Bijak, J.; Siadkowski, A.; Bijak, M. Molecular aspects of mycotoxins-a serious problem for human health. Int. J. Mol. Sci. 2020, 21, 8187. [CrossRef] [PubMed]

18. Commission Regulation (EC) No 1881/2006 of 19 December 2006. Setting Maximum Levels for Certain Contaminants in Foodstuffs Available online: https:/ / eur-lex.europa.eu/legal-content/EN/ALL/?uri=celex\%3A32006R1881 (accessed on 8 July 2021).

19. El Jai, A.; Juan, C.; Juan-García, A.; Mañes, J.; Zinedine, A. Multi-mycotoxin contamination of green tea infusion and dietary exposure assessment in Moroccan population. Int. Food Res. J. 2021, 140, 109958. [CrossRef] [PubMed]

20. Bennett, J.W.; Klich, M. Mycotoxins. Clin. Microbiol. Rev. 2003, 36, 497-516. [CrossRef]

21. Giovati, L.; Magliani, W.; Ciociola, T.; Santinoli, C.; Conti, S.; Polonelli, L. AFM1 in milk: Physical, biological, and prophylactic methods to mitigate contamination. Toxins 2015, 7, 4330-4349. [CrossRef] [PubMed]

22. Pitt, J.; Miller, J.D. A concise history of mycotoxin research. J. Agric. Food Chem. 2017, 65, 7021-7033. [CrossRef] [PubMed]

23. Peraica, M.; Radić, B.; Lucić, A.; Pavlović, M. Toxic effects of mycotoxins in human. Bull. World Health Organ. 1999, 77, 754-766.

24. Hyvönen, S.; Lohi, J.; Tuuminen, T. Moist and mold exposure is associated with high prevalence of neurological symptoms and MCS in a Finnish hospital workers cohort. Saf. Health Work 2020, 11, 173-177. [CrossRef]

25. Campbell, A.W.; Decena, K. The brain and mycotoxins. Altern. Ther. Health Med. 2020, 26, 8-11. [PubMed]

26. Campbell, A.W.; Watson, P. Mold, mycotoxins and their effects in children. Altern. Ther. Health Med. 2021, 27, 8-11. [PubMed]

27. IARC. Monographs on the evaluation of carcinogenic risks to humans. IARC Monogr. 2012, 100E, 333-364.

28. Tarannum, N.; Nipa, M.N.; Das, S.; Parveen, S. Aflatoxin M1 detection by ELISA in raw and processed milk in Bangladesh. Toxicol. Rep. 2020, 7, 1339-1343. [CrossRef] [PubMed]

29. Pauletto, M.; Giantin, M.; Tolosi, R.; Bassan, I.; Barbarossa, A.; Zaghini, A.; Dacasto, M. Discovering the protective effects of resveratrol on aflatoxin B1-induced toxicity: A whole transcriptomic study in a bovine hepatocyte cell line. Antioxidants 2021, 10, 1225. [CrossRef]

30. Negash, D. A review of Aflatoxin: Occurrence, prevention, and gaps in both food and feed safety. J. Appl. Microb. Res. 2018, 1, 35-43. [CrossRef]

31. Piotrowska, M.; Masek, A. Saccharomyces cerevisiae cell wall components as tools for ochratoxin A decontamination. Toxins 2015, 7, 1151-1162. [CrossRef] [PubMed]

32. Stoev, S.D.; Paskalev, M.; MacDonald, S.; Mantle, P.G. Experimental one-year ochratoxin A toxicosis in pigs. Exp. Toxicol. Pathol. 2002, 53, 481-487. [CrossRef] [PubMed]

33. Liang, R.; Shen, X.L.; Zhang, B.; Li, Y.; Xu, W.; Zhao, C.; Luo, Y.; Huang, K. Apoptosis signal-regulating kinase 1 promotes Ochratoxin A-induced renal cytotoxicity. Sci. Rep. 2015, 28, 8078. [CrossRef] [PubMed]

34. IARC. Monographs on the evaluation of carcinogenic risks to humans: Some naturally occurring substances: Food items and constituents, heterocyclic aromatic amines and mycotoxins. Int. Agency Res. Cancer 1993, 56, 1-599.

35. Zadravec, M.; Vahčić, N.; Brnić, D.; Markov, K.; Frece, J.; Beck, R.; Lešić, T.; Pleadin, J. A study of surface moulds and mycotoxins in Croatian traditional dry-cured meat products. Int. J. Food Microbiol. 2020, 317, 108459. [CrossRef] [PubMed]

36. Damiano, S.; Longobardi, C.; Andretta, E.; Prisco, F.; Piegari, G.; Squillacioti, C.; Montagnaro, S.; Pagnini, F.; Badino, P.; Florio, S.; et al. Antioxidative effects of curcumin on the hepatotoxicity induced by ochratoxin A in rats. Antioxidants 2021, 10, 125. [CrossRef] [PubMed]

37. Vahedi, H. A Study on rice and bread contamination with ochratoxin A, Balkan Endemic Nephropathy agent. Clin. Exc. 2018, 7, 28-46.

38. Stoyanov, G.S.; Kobakova, I.; Petkova, L.; Dzhenkov, D.L.; Popov, H. Balkan Endemic Nephropathy: An autopsy case report. Cureus 2021, 13, e12415. [CrossRef] 
39. Lucchetta, G.; Bazzo, I.; Cortivo, G.D.; Stringher, L.; Bellotto, D.; Borgo, M.; Angelini, E. Occurrence of black aspergilli and ochratoxin A on grapes in Italy. Toxins 2010, 2, 840-855. [CrossRef]

40. Lappa, I.K.; Mparampouti, S.; Lanza, B.; Panagou, E.Z. Control of Aspergillus carbonarius in grape berries by Lactobacillus plantarum: A phenotypic and gene transcription study. Int. J. Food Microbiol. 2018, 275, 56-65. [CrossRef]

41. McCormick, S.P.; Stanley, A.M.; Stover, N.A.; Alexander, N.J. Trichothecenes: From simple to complex mycotoxins. Toxins 2011, 3, 802-814. [CrossRef]

42. Stroka, J.; Goncalves, C. 2019. Mycotoxins in food and feed: An overview. Food Chem. 2019, 1, 401-419.

43. Mielniczuk, E.; Skwaryło-Bednarz, B. Fusarium head blight, mycotoxins and strategies for their reduction. Agronomy 2020, 10, 509. [CrossRef]

44. Payros, D.; Ménard, S.; Laffitte, J.; Neves, M.; Tremblay-Franco, M.; Luo, S.; Fouche, E.; Snini, S.P.; Theodorou, V.; Pinton, P.; et al. The food contaminant, deoxynivalenol, modulates the Thelper/Treg balance and increases inflammatory bowel diseases. Arch. Toxicol. 2020, 94, 3173-3184. [CrossRef] [PubMed]

45. Ruan, F.; Chen, J.G.; Chen, L.; Lin, X.T.; Zhou, Y.; Zhu, K.; Guo, Y.T.; Tan, A.J. Food Poisoning Caused by Deoxynivalenol at a School in Zhuhai, Guangdong, China, in 2019. Foodborne Pathog. Dis. 2020, 17, 429-433. [CrossRef] [PubMed]

46. Srey, C.; Kimanya, M.E.; Routledge, M.N.; Shirima, C.P.; Gong, Y.Y. Deoxynivalenol exposure assessment in young children in Tanzania. Mol. Nutr. Food Res. 2014, 58, 1574-1580. [CrossRef] [PubMed]

47. Urbanek, K.A.; Habrowska-Górczyńska, D.E.; Kowalska, K.; Stańczyk, A.; Domińska, K.; Piastowska-Ciesielska, A.W. Deoxynivalenol as potential modulator of human steroidogenesis. J. Appl. Toxicol. 2018, 38, 1450-1459. [CrossRef]

48. Ropejko, K.; Twarużek, M. Zearalenone and its metabolites-general overview, occurrence, and toxicity. Toxins 2021, 13, 35. [CrossRef] [PubMed]

49. Alshannaq, A.; Yu, J.H. Occurrence, toxicity, and analysis of major mycotoxins in food. Int. J. Environ. Res. Public Health 2017, 14, 632. [CrossRef]

50. Pałubicki, J.; Kosicki, R.; Twarużek, M.; Ałtyn, I.; Grajewski, J. Concentrations of zearalenone and its metabolites in female wild boars from woodlands and farmlands. Toxicon 2021, 196, 19-24. [CrossRef] [PubMed]

51. Kowalska, K.; Habrowska-Górczyńska, D.E.; Piastowska-Ciesielska, A.W. Zearalenone as an endocrine disruptor in humans. Environ. Toxicol. Pharmacol. 2016, 48, 141-149. [CrossRef]

52. Yang, R.; Wang, Y.M.; Zhang, L.; Zhao, Z.M.; Zhao, J.; Peng, S.Q. Prepubertal exposure to an oestrogenic mycotoxin zearalenone induces central precocious puberty in immature female rats through the mechanism of premature activation of hypothalamic kisspeptin-GPR54 signaling. Mol. Cell Endocrinol. 2016, 9, 62-74. [CrossRef] [PubMed]

53. Kriszt, R.; Krifaton, C.; Szoboszlay, S.; Cserhati, M.; Kriszt, B.; Kukolya, J. A new zearalenone biodegradation strategy using non-pathogenic Rhodococcus pyridinivorans K408 strain. PLoS ONE 2012, 7, e43608. [CrossRef] [PubMed]

54. Złoch, M.; Rogowska, A.; Pomastowski, P.; Railean-Plugaru, V.; Walczak-Skierska, J.; Rudnicka, J.; Buszewski, B. Use of Lactobacillus paracasei strain for zearalenone binding and metabolization. Toxicon 2020, 181, 9-18. [CrossRef] [PubMed]

55. Munkvold, G.P.; Arias, S.; Taschl, I.; Gruber-Dorninger, C. Mycotoxins in Corn: Occurrence, Impacts, and Management. In Corn: Chemistry and Technology, 3rd ed.; Serna-Saldivar, S.O., Ed.; AACC International Press: Washington, DC, USA, 2019 ; pp. $235-287$.

56. Stockmann-Juvala, H.; Naarala, J.; Loikkanen, J.; Vähäkangas, K.; Savolainen, K. Fumonisin B1-induced apoptosis in neuroblastoma, glioblastoma and hypothalamic cell lines. Toxicology 2006, 225, 234-241. [CrossRef] [PubMed]

57. Lumsangkul, C.; Chiang, H.I.; Lo, N.W.; Fan, Y.K.; Ju, J.C. Developmental toxicity of mycotoxin Fumonisin B1 in animal embryogenesis. Toxins 2019, 11, 114. [CrossRef]

58. Laurain, J.; Tardieu, D.; Matard-Mann, M.; Rodriguez, M.A.; Guerre, P. Fumonisin B1 accumulates in chicken tissues over time and this accumulation was reduced by feeding algo-clay. Toxins 2021, 13, 701. [CrossRef] [PubMed]

59. Kovač, M.; Šubarić, D.; Bulaić, M.; Kovač, T.; Šarkanj, B. Yesterday masked, today modified; what do mycotoxins bring next? Arh. Hig. Rada Toksikol. 2018, 69, 196-214. [CrossRef]

60. Freire, L.; Guerreiro, T.M.; Caramês, E.T.S.; Lopes, L.S.; Orlando, E.A.; Pereira, G.E.; Lima Pallone, J.A.; Catharino, R.R.; Sant'Ana, A.S. Influence of maturation stages in different varieties of wine grapes (Vitis vinifera) on the production of Ochratoxin A and its modified forms by Aspergillus carbonarius and Aspergillus niger. J. Agric. Food Chem. 2018, 66, 8824-8831. [CrossRef]

61. Berthiller, F.; Crews, C.; Dall'Asta, C.; Saeger, S.D.; Haesaert, G.; Karlovsky, P.; Oswald, I.P.; Seefelder, W.; Speijers, G.; Stroka, J. Masked mycotoxins: A review. Mol. Nutr. Food Res. 2013, 57, 165-186. [CrossRef]

62. Dall'Erta, A.; Cirlini, M.; Dall'Asta, M.; Del Rio, D.; Galaverna, G.; Dall'Asta, C. Masked mycotoxins are efficiently hydrolyzed by human colonic microbiota releasing their aglycones. Chem. Res. Toxicol. 2013, 26, 305-312. [CrossRef]

63. Scarpino, V.; Vanara, F.; Sulyok, M.; Krska, R.; Blandino, M. Fate of regulated, masked, emerging mycotoxins and secondary fungal metabolites during different large-scale maize dry-milling processes. Food Res. Int. 2020, 141, 109861. [CrossRef] [PubMed]

64. Rychlik, M.; Humpf, H.U.; Marko, D.; Danicke, S.; Mally, A.; Berthiller, F.H.; Lorenz, N. Proposal of a comprehensive definition of modified and other forms of mycotoxins including "masked" mycotoxins. Mycotoxin Res. 2014, 30, 197-205. [CrossRef] [PubMed]

65. Palumbo, R.; Crisci, A.; Venâncio, A.; Cortiñas Abrahantes, J.; Dorne, J.-L.; Battilani, P.; Toscano, P. Occurrence and co-occurrence of mycotoxins in cereal-based feed and food. Microorganisms 2020, 8, 74. [CrossRef] [PubMed]

66. Bocianowski, J.; Szulc, P.; Waśkiewicz, A.; Cyplik, A. The effect of agrotechnical factors on Fusarium mycotoxins level in maize. Agriculture 2020, 10, 528. [CrossRef] 
67. Cleveland, T.E.; Dowd, P.F.; Desjardins, A.E.; Bhatnagar, D.; Cotty, P.J. United States Department of Agriculture-Agricultural Research Service research on pre-harvest prevention of mycotoxins and mycotoxigenic fungi in US crops. Pest. Manag. Sci. 2003, 59, 629-642. [CrossRef]

68. Wagacha, J.M.; Muthomi, J.W. Mycotoxin problem in Africa: Current status, implications to food safety and health and possible management strategies. Int. J. Food Microbiol. 2008, 124, 1-12. [CrossRef] [PubMed]

69. Luo, Y.; Liu, X.; Yuan, L.; Li, J. Complicated interactions between bio-adsorbents and mycotoxins during mycotoxin adsorption: Current research and future prospects. Trends Food Sci. Technol. 2020, 96, 127-134. [CrossRef]

70. Sadiq, F.A.; Yan, B.; Tian, F.; Zhao, J.; Zhang, H.; Chen, W. Lactic acid bacteria as antifungal and anti-mycotoxigenic agents: A comprehensive review. Compr. Rev. Food Sci. Food Saf. 2019, 18, 1403-1436. [CrossRef]

71. Volkova, G.S.; Kuksova, E.V.; Serba, E.M. Prevention of mycotoxicoses in broiler chickens exposed to a mycotoxin-contaminated diet. Russ. Agric. Sci. 2021, 47, 161-165. [CrossRef]

72. Semenov, E.I.; Mishina, N.N.; Saitov, V.R.; Perfilova, K.V.; Kashevarov, G.S.; Tanaseva, S.A.; Idiyatov, I.I.; Tarasova, E.Y.; Matrosova, L.E.; Shlyamina, O.V.; et al. Effect of bee brood and zeolite on broiler chickens exposed by mycotoxin t-2. nat. Volatiles Essent. Oils 2021, 8, 3520-3531.

73. Ramos-Tovar, E.; Muriel, P. Free radicals, antioxidants, nuclear factor-E2-related factor-2 and liver damage. J. Appl. Toxicol. 2020, 40, 151-168. [CrossRef] [PubMed]

74. Sharma, V.; Patial, V. Food mycotoxins: Dietary interventions implicated in the prevention of mycotoxicosis. Food Sci. Technol. 2021, 1, 1717-1739. [CrossRef]

75. Pigłowski, M. Comparative analysis of notifications regarding mycotoxins in the Rapid Alert System for Food and Feed (RASFF). Qual. Assur. Saf. Crop. Foods 2019, 11, 725-735. [CrossRef]

76. Ramos-Diaz, J.M.; Sulyok, M.; Jacobsen, S.E.; Jouppila, K.; Nathanail, A.V. Comparative study of mycotoxin occurrence in Andean and cereal grains cultivated in South America and North Europe. Food Control. 2021, 130, 108260. [CrossRef]

77. Alaboudi, A.R.; Osaili, T.M.; Otoum, G. Quantification of mycotoxin residues in domestic and imported chicken muscle, liver and kidney in Jordan. Food Control. 2022, 132, 108511. [CrossRef]

78. Van Deventer, M.M.; Pretorius, B.; Schönfeldt, H.C. A preliminary study on mycotoxin contamination in red meat from registered abattoirs in South Africa. Mycotoxin Res. 2021, 37, 105-108. [CrossRef] [PubMed]

79. Memiş, E.Y.; Yalçın, S.S. Human milk mycotoxin contamination: Smoking exposure and breastfeeding problems. J. Matern. Fetal Neonatal Med. 2021, 34, 31-40. [CrossRef]

80. Braun, D.; Eiser, M.; Puntscher, H.; Marko, D.; Warth, B. Natural contaminants in infant food: The case of regulated and emerging mycotoxins. Food Control 2021, 123, 107676. [CrossRef]

81. Kęińska-Pacelik, J.; Biel, W. Microbiological hazards in dry dog chews and feeds. Animals 2021, 11, 631. [CrossRef] [PubMed]

82. Vudathala, D.; Klobut, J.; Cummings, M.; Tkachenko, A.; Reimschuessel, R.; Murphy, L. Collaborators, multilaboratory evaluation of a lateral flow method for aflatoxin B1 analysis in dry dog food. J. AOAC Int. 2020, 103, 480-488. [CrossRef]

83. Commission Recommendation (EU) 2016/1319 of 29 July 2016. Amending Recommendation 2006/576/EC as Regards Deoxynivalenol, Zearalenone and Ochratoxin A in Pet Food (Text with EEA Relevance). Available online: https:/ / eur-lex.europa.eu/ legal-content/EN/TXT/?uri=CELEX\%3A32016H1319 (accessed on 8 July 2021).

84. Laca, A.; Mousia, Z.; Diaz, M.; Webb, C.; Pandiella, S.S. Distribution of microbial contamination within cereal grains. J. Food Eng. 2006, 72, 332-338. [CrossRef]

85. Oliveira, P.M.; Zannini, E.; Arendt, E.K. Cereal fungal infection, mycotoxins, and lactic acid bacteria mediated bioprotection: From crop farming to cereal products. Food Microbiol. 2013, 37, 78-95. [CrossRef] [PubMed]

86. Atanda, S.A.; Pessu, P.O.; Agoda, S.; Isong, I.U.; Adekalu, O.A.; Echendu, M.A.; Falade, T.C. Fungi and mycotoxins in stored foods. Afr. J. Microbiol. Res. 2011, 5, 4373-4382. [CrossRef]

87. Santos Pereira, C.C.; Cunha, S.; Fernandes, J.O. Prevalent mycotoxins in animal feed: Occurrence and analytical methods. Toxins 2019, 11, 290. [CrossRef]

88. Vudathala, D.; Cummings, M.; Tkachenko, A.; Guag, J.; Reimschuessel, R.; Murphy, L. A lateral flow method for aflatoxin B1 in dry dog food: An inter-laboratory trial. J. AOAC Int. 2021, 104, 555-561. [CrossRef]

89. Witaszak, N.; Waskiewicz, A.; Bocianowski, J.; Stepien, Ł. Contamination of pet food with mycobiota and Fusarium mycotoxinsFocus on dogs and cats. Toxins 2020, 12, 130. [CrossRef]

90. Zain, M.E. Impact of mycotoxins on humans and animals. J. Saudi Chem. Soc. 2011, 15, 129-144. [CrossRef]

91. Da Rocha, M.E.B.; Freire, F.D.C.O.; Maia, F.E.F.; Guedes, M.I.F.; Rondina, D. Mycotoxins and their effects on human and animal health. Food Control. 2014, 36, 159-165. [CrossRef]

92. Agriopoulou, S.; Stamatelopoulou, E.; Varzakas, T. Advances in occurrence, importance, and mycotoxin control strategies: Prevention and detoxification in foods. Foods 2020, 9, 137. [CrossRef] [PubMed]

93. Arenas-Huertero, F.; Zaragoza-Ojeda, M.; Sánchez-Alarcón, J.; Milic, M.; Šegvic Klaric, M.; Montiel-González, J.M.; ValenciaQuintana, R. Involvement of ahr pathway in toxicity of aflatoxins and other mycotoxins. Front. Microbiol. $2019,10,2347$. [CrossRef] [PubMed]

94. Muhammad, I.; Sun, X.; Wang, H.; Li, W.; Wang, X.; Cheng, P.; Li, S.; Zhang, X.; Hamid, S. Curcumin successfully inhibited the computationally identified CYP2A6 enzyme-mediated bioactivation of aflatoxin B1 in arbor acres broiler. Front. Pharmacol. 2017, 8, 143. [CrossRef] [PubMed] 
95. Chukwuka, O.K.; Okoli, I.C.; Opara, M.N.; Omede, A.A.; Ogbuewu, I.P.; Iheshiulor, O.O.M. The growing problems of mycotoxins in animal feed industry in West Africa. Asian J. Poult. Sci. 2010, 4, 122-134. [CrossRef]

96. Singh, S.D.; Chuturgoon, A.A. A comparative analysis of mycotoxin contamination of supermarket and premium brand pelleted dog food in Durban, South Africa. J. S. Afr. Vet. Assoc. 2017, 88, 1-6. [CrossRef] [PubMed]

97. Leiva, A.; Molina, A.; Redondo-Solano, M.; Artavia, G.; Rojas-Bogantes, L.; Granados-Chinchilla, F. Pet food quality assurance and safety and quality assurance survey within the Costa Rican pet food industry. Animals 2019, 9, 980. [CrossRef] [PubMed]

98. Leiva, A.; Méndez, G.; Rodriguez, C.; Molina, A.; Granados-Chinchilla, F. Chemical assessment of mycotoxin contaminants and veterinary residues in Costa Rican animal feed. Int. J. Food Contam. 2019, 6, 1-26. [CrossRef]

99. Pietsch, C. Risk assessment for mycotoxin contamination in fish feeds in Europe. Mycotoxin Res. 2020, 36, 41-62. [CrossRef]

100. Liu, N.; Liu, C.; Dudaš, T.N.; Loc, M.Č.; Bagi, F.F.; van der Fels-Klerx, H.J. Improved aflatoxins and fumonisins forecasting models for maize (PREMA and PREFUM), using combined mechanistic and bayesian network modeling-serbia as a case study. Front. Microbiol. 2021, 12, 643604. [CrossRef]

101. Twarużek, M.; Skrzydlewski, P.; Kosicki, R.; Grajewski, J. Mycotoxins survey in feed materials and feedingstuffs in years 2015-2020. Toxicon 2021, 202, 27-39. [CrossRef]

102. Shao, M.; Li, L.; Gu, Z.; Yao, M.; Xu, D.; Fan, W.; Yan, L.; Song, S. Mycotoxins in commercial dry pet food in China. Food Addit. Contam. 2018, 11, 237-245. [CrossRef]

103. Tegzes, J.H.; Oakley, B.B.; Brennan, G. Comparison of mycotoxin concentrations in grain versus grain-free dry and wet commercial dog food. Toxicol. Commun. 2019, 3, 61-66. [CrossRef]

104. Kępińska-Pacelik, J.; Biel, W. Microbiological Hazards in Pet Foods. Available online: https:/ / encyclopedia.pub/8619 (accessed on 3 September 2021).

105. Witaszak, N.; Stępień, Ł.; Bocianowski, J.; Waśkiewicz, A. Fusarium species and mycotoxins contaminating veterinary diets for dogs and cats. Microorganisms 2019, 7, 26. [CrossRef] [PubMed]

106. Macias-Montes, A.; Rial-Berriel, C.; Acosta-Dacal, A.; Henríquez-Hernández, L.A.; Almeida-González, M.; Rodríguez-Hernández, A.; Zumbado, M.; Boada, L.D.; Zaccaroni, A.; Luzardo, O.P. Risk assessment of the exposure to mycotoxins in dogs and cats through the consumption of commercial dry food. Sci. Total Environ. 2019, 708, 134592. [CrossRef]

107. Okuma, T.A.; Huynh, T.P.; Hellberg, R.S. Use of enzyme-linked immunosorbent assay to screen for aflatoxins, ochratoxin A, and deoxynivalenol in dry pet foods. Mycotoxin Res. 2018, 34, 69-75. [CrossRef] [PubMed]

108. Gazzotti, T.; Biagi, G.; Pagliuca, G.; Pinna, C.; Scardilli, M.; Grandi, M.; Zaghini, G. Occurrence of mycotoxins in extruded commercial dog food. Anim. Feed. Sci. Technol. 2015, 202, 81-89. [CrossRef]

109. Uhlig, S.; Ivanova, L.; Voorspoels, P.; Fæste, C.K. In vitro toxicokinetics and phase I biotransformation of the mycotoxin Penitrem A in dogs. Toxins 2020, 12, 293. [CrossRef] [PubMed]

110. Maragos, C.M. Development and characterisation of a monoclonal antibody to detect the mycotoxin roquefortine C. Food Addit. Contam. Part. A 2020, 37, 1777-1790. [CrossRef]

111. González, N.; Marquès, M.; Nadal, M.; Domingo, J.L. Occurrence of environmental pollutants in foodstuffs: A review of organic vs. conventional food. Food Chem Toxicol. 2019, 125, 370-375. [CrossRef]

112. Pleadin, J.; Staver, M.M.; Markov, K.; Frece, J.; Zadravec, M.; Jaki, V.; Krupić, I.; Vahčić, N. Mycotoxins in organic and conventional cereals and cereal products grown and marketed in Croatia. Mycotoxin Res. 2017, 33, 219-227. [CrossRef] [PubMed] 